Historic, Archive Document

Do not assume content reflects current scientific knowledge, policies, or practices. 



\section{TENTH ANNUAL CATALOGUE AND PRICE LIST}

\section{PLANT

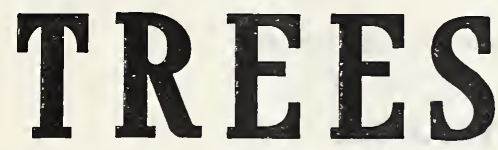

QVERGREEN

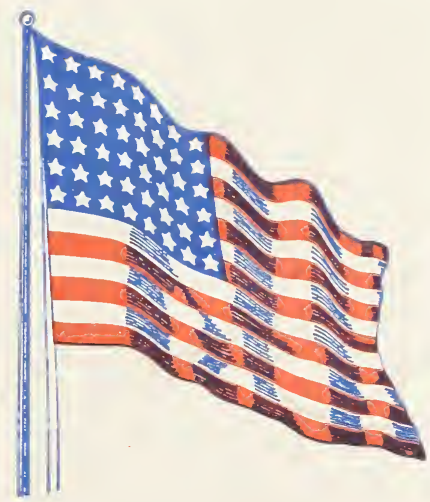

1918

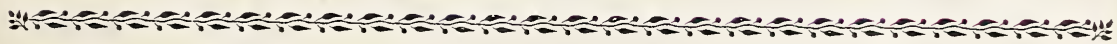
SAGINAW, - MICHIGAN 


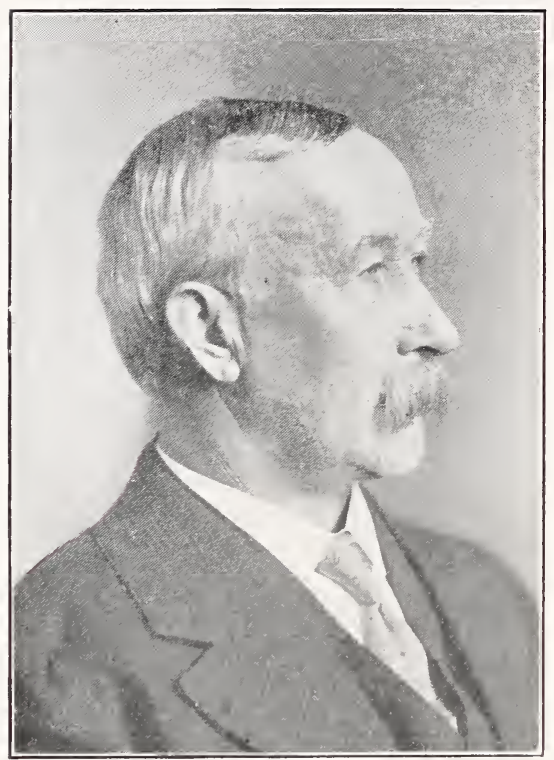

\section{Evergreen Nursery, January 10, 1918.}

Friends and Patrons:

Please permit me to present to you this my Tenth Annual Catalog and Price List. Accept my thanks for your generous support in the past and let me beg for your good will also in the future.

Thanking you again, I am, Sincerely yours, VAL KATZENBERGER.

POST OFFICE ADDRESS-As my nursery is located outside of the city and on the direct line of Rural Route No. 2, Fosters, all correspondence should be addressed that way.

\section{TELEPHONE-Call Valley X1431.}

LOCATION_For location see map on last cover page.

TERMS-Cash on delivery. Payments may be made by cash, check, Post Office or Express Order.

POSTAGE, FREIGHT or EXPRESS CHARGES must be paid by the purchaser and should be included in the remittance if charges are to be prepaid.

DELIVERIE $\dot{S}$ will be made at central points in Saginaw free of charge.

GUARANTEE-I will furnish live and healthy trees and plants, but can not agree to replace plants that are destroyed by causes over which I have no control. Plants and trees that are not satisfactory when received may be returned and money paid for the same will be cheerfully refunded.

PRICES.-Except on a few items my prices are the same as last year and include proper packing. As packing material-paper, sacking and string -has practically doubled in price, my profit on very small orders will be lost; while I am thankful for small orders always, larger ones will be more profitable and welcome in proportion. 


\section{EVERGREENS}

The subject of Evergreens needs no introduction. We all know the beauty and usefulness of the Evergreens - once our State was covered with the Pines, Spruces and Cedars. Now the wind sweeps the State from shore to shore; storms spread desolation over the land, and we are at the mercy of the cyclone and hurricane. We can do much to check the wind. One little shrub will afford shelter; we should plant more of them. We should go further, we should plant trees - we should plant Evergreens.

I offer nice trees with roots at prices within the reach of all.

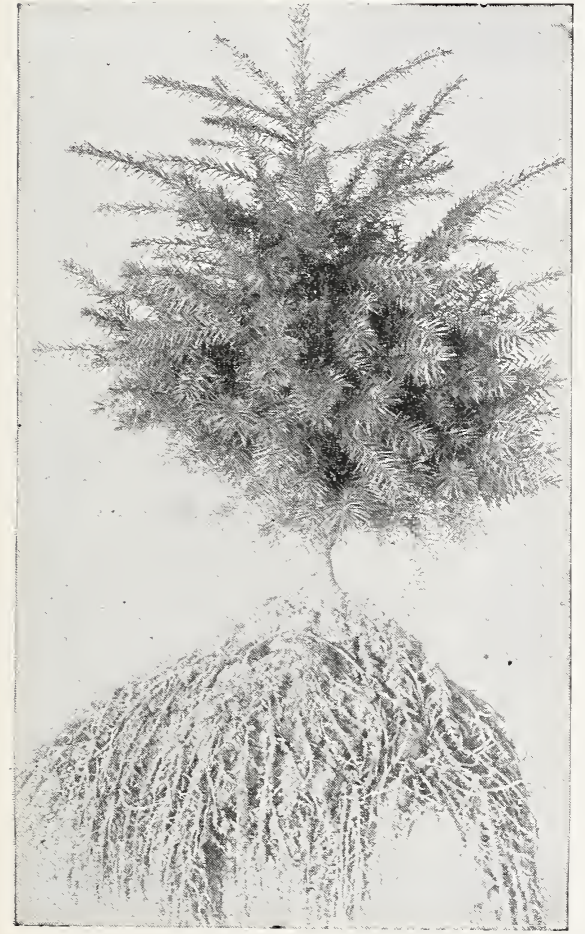

American Arbor Vitæ

Specimen 5 to 6 feet......\$1.50

Specimen 4 to 5 feet...... 1.00

Specimen 3 to 4 feet...... .75

Pyramidalis, 3 feet ...... 1.00

\section{Balsam Fir}

Specimen 3 feet........ 1.00

Specimen 2 feet......... .50

\section{European Silver Fir}

Specimen 2 fet $\ldots \ldots \ldots \ldots, .75$

\section{Irish Juniper}

Specimen 2 to 3 feet...... 1.00

Specimen 18 inches....... .75

\section{Savin Juniper}

Specimen 1 foot........ .75

English Juniper

Specimen 3 to 4 feet...... 2.00

Red Cedar

Specimen 2 to 3 feet...... 1.00

Hemlock Spruce

Specimen 3 feet........ 1.00

Specimen 2 fet ........ .75

Norway Spruce

Specimen 4 feet........ 1.00

Specimen 3 feet......... .50

Specimen 2 feet......... .25

Seedlings transplanted, 10 to

12 inches ............ .10

White Spruce

Transplant Seedlings, 10 to

12 inches ...........

Colorado Blue Spruce

Specimen 2 to 3 feet......

Austrian Pine

Specimen 2 feet.........

\section{Ponderosa Pine}

Specimen 3 to 4 feet...... 1.00

Specimen 2 to 3 feet...... .75

Scotch Pine, 12 to 15 inches... .20

Jack Pine, 15 inches ....... . .15

White Pine, 12 inches....... . 10

Mugho Pine, 10 inches. . . . . . .50 


\section{DECIDUOUS TREES}

\section{Catalpa Speciosa}

8 to 10 feet.........\$0.75

6 to 8 feet............50

\section{Russian Mulberry}

6 to 8 feet............ .75

European Larch (straight as candles)

7 to 8 feet........... 1.00

6 to 7 feet............. .50
Ash-Leaf Maple

Fine specimen 7 to 8 feet... $\quad .75$

Mountain Ash

6 to 7 feet..............50

5 to 6 feet............. .35

Purple-Leafed Plum

4 to 5 feet ........... .50

Black Walnut

Transplanted seedlings, 4 ft. .25

American Sweet Chestnut

12 to 15 inches ...........15

\section{VINES AND CLIMBERS}

Hall's Japan Honeysuckle

3Three years old ....... .25

Bignonia (Trumpet Flower) ... . .25

Wistaria (Purple) ......... .25

American Ivy ........... .25

Boston Ivy ............ .25

Bittersweet ........... 25
Cinnamon Vines (Bulbs)..... .25

Vinca Minor (Periwinkle)

Rooted runners, per 12.... .25

Clematis Paniculata, 2-year.... .25

Clematis Jackmann (purple... .50

Clematis Henry, white ..... .50

Clematis Coccinea, red ..... .25

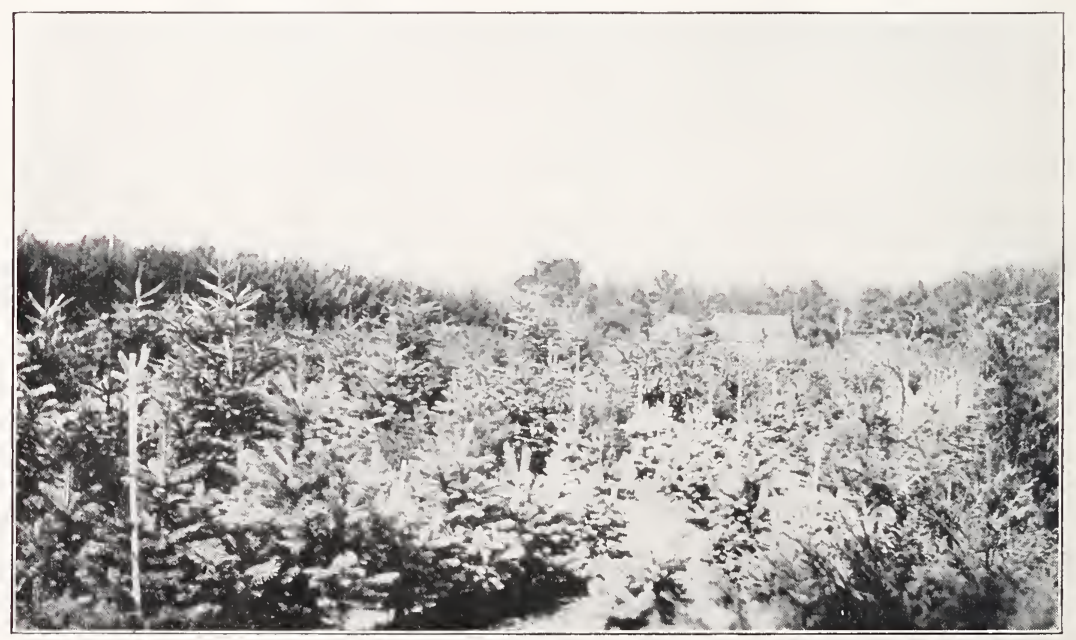

Blue Spruce 


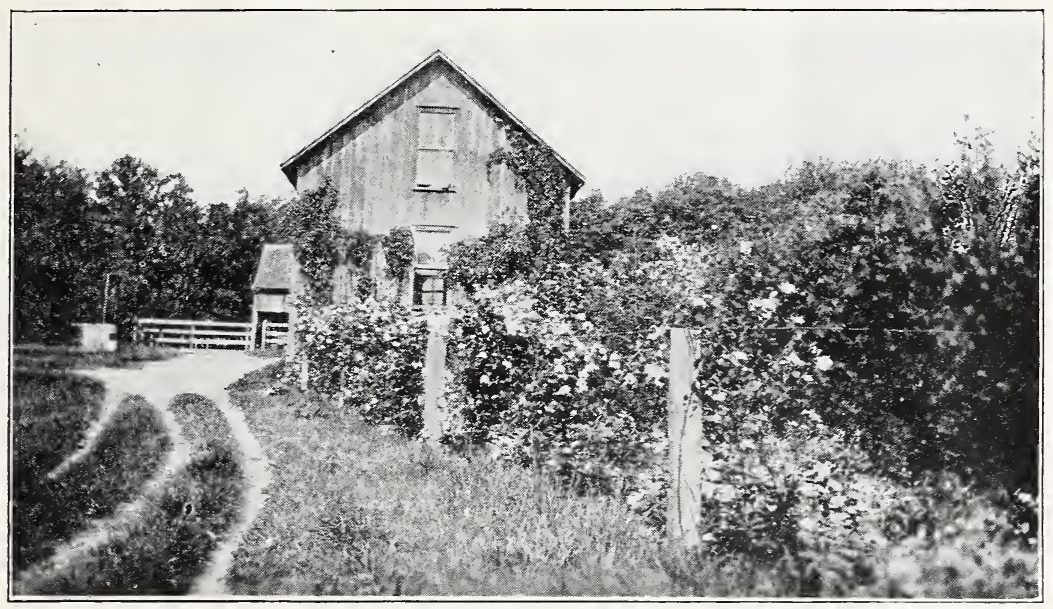

A Corner in Flowers

\section{ROSES}

Crimson Rambler .........\$0.35 Hermosa (everblooming) ..... .35

Lady Gay (pink) .................. . .35 Paul Neyron (very large) ....

Dorothea Perkins (pink)..... .35 Frau Carl Druschke (white)... $\quad .35$

Source De'Or (yellow)...... .35 Coquette des Alps (white)... .35

Crimson Baby .................... . .35

Baby Dorothea (pink) ....... .25 Tree Roses, each ......... 1.00

American Beauty (pink) ..... .35 Ulrich Brunner (dark red) ... ${ }_{35}$

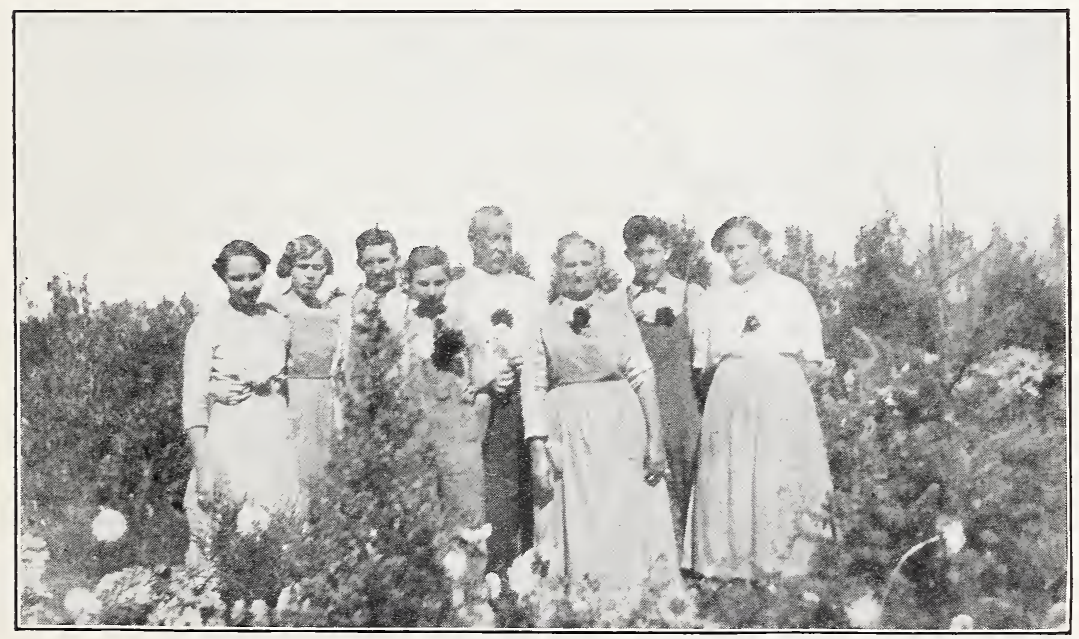




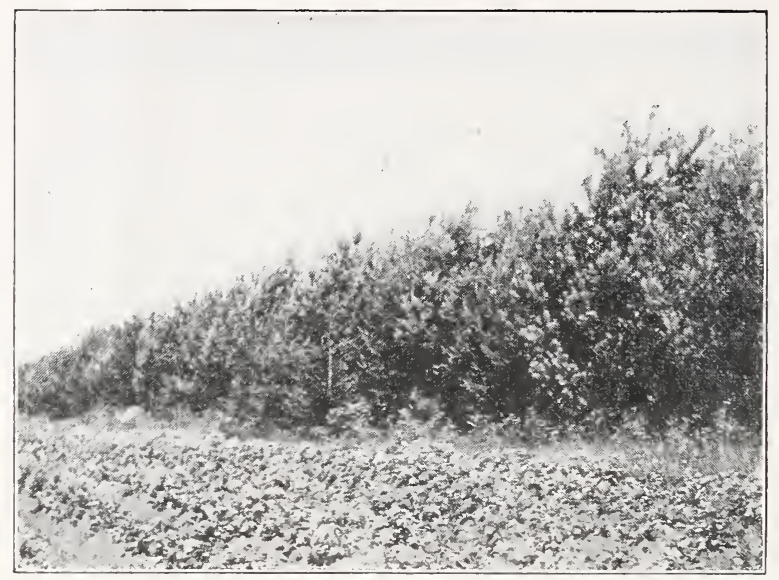

Scotch Pine Windbreak

\section{FLOWERING SHRUBS}

Flowering Almonds

White and Pink, each.....\$0.50

\section{Barberries}

Purple leaf ...............

Thunbergi Dwarf, 12-inch... .15

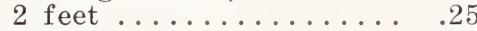

Japan Quince ............ .25

Corchorus

Variegated Silver-leaf ..... .25

Rhodatyphus (white-flowered). .25

Forsythia (golden bell) $3 \mathrm{ft} . . .25$

Eunominus, Wah ........ .50

Hydrangea

Paniculata (tree form) ... 1.00

Grandiflora ........... . .50

Arborescens ............. .50

Lilac

Common Purple ........ .25

Persian White ............. .50

Ludwig Spaeth (blue)..... $\quad .50$

Maria La Gray (double white) $\quad .50$

Tartarian Honeysuckle

Pink and white, each
Privet

California .............15

Ibota (hardy) ........... .15

Riegel (flowering) ....... .25

Prunus Pissardi

Purple-leafed Plum 3-4.... .50

Prunus Triloba

Rose Tree of China ....... . .50

Syringa or Mock Orange

Large Flowering ......... . .50

Sweet Flowered ........... .25

Golden Leafed ......... . .25

\section{Spirea}

Van Houti, 21/2 feet ...... .25

Anthony Waterer, dwarf, pink .25

Aurea, golden leafed...... .25

\section{Snowball}

Common .......................

Japan ................... 50

Highbush Cranberry ...... .25

Snowberry, white ........ .25

Waxberry, red .......... .25

.50 Weigelia Rosea ........... . .50

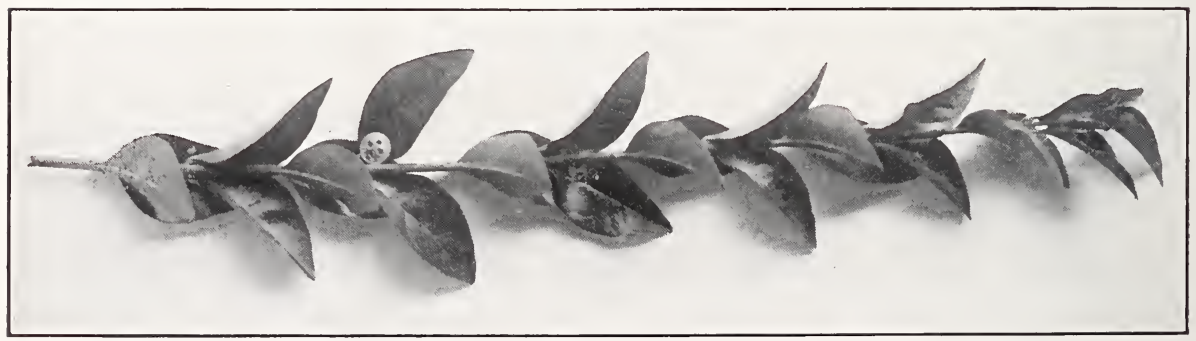




\section{HARDY PERENNIALS}

\section{Peonaes}

These lovely flowers are coming into their own again. Hardy, with no enemies (except a shady piace) they ask few favors aside from a sunny situation. They come in many different colors from pure white to dark red, and many shades of pink. Small divisions, 3 to 5 eyes.....\$ $\$ 0.25$ Large divisions, 5 to 7 eyes. . .50

Pholx, 2-year clumps....... .25 Beauty (silvery pink).

Bearanger (white amaranth eye). Bridesmaid (white with red center).

Independence (pure white).

Jules Campou (magenta).

Peach Blow.
Struthers (cerise).

Lily of the Valley, 3-yr. clumps .25

Bleeding Heart, large division. .25

Foxglove

Large, per $12 \ldots \ldots \ldots \ldots . .50$

Small, per $12 \ldots \ldots \ldots \ldots . .25$

Marvel Mallows

Red, pink and white, each...

German Iris

Blue, purple, white or yellow, each purple, white or yellow,

Sweet Violet, double blue

Whole clumps ..........

Creeping Pholx or Moss Pink

Mosslike foliage and covered a long time with small pink flowers.

Oriental Poppies

Mostly scarlet flowers ......

\section{MISCELLANEOUS}

\section{Asparagus}

Roots, 2 years, per $12 \ldots \ldots \$ 0.25$

\section{Rhubarb}

Cosmos Seed

Large early blooming packet.

Two-year roots, per $12 \ldots . . \quad .60$

Gensing Seed.

Golden Seal (buds).

Grafting Wax, per to .......

\section{GLADIOLI}

America (flesh pink).

Augusta (white-blue anthers).

Europe (pure white).

Kunderly Glory (ruffled edges).

Independence (rosy pink).

Mrs. Francis King (bright scarlet)..

Panama, an improved America.

Pink Beauty, rich deep pink with distince red blotch.
Sulphur King, yellow, strong, upright.

Princeps, rich crimson with white blotch.

Selected-75́c per 12.

\section{Gladioli Mixtures}

I have on hand a large number of mixed bulbs that will fit well into all informal plantings. As long as the stock holds out I will sell these large bulbs at $\$ 2.00$ per 100 ; small bulbs at $\$ 1.00$ per 100 . 


\section{DAHLIAS}

\section{Show Dahlias}

"Eclipse," large and full, crimson scarlet.

“Eurica," large, yellow shaded salmon pink.

"Livonia," medium size, deep pink, perfect.

"Grand Duke Alexis," large, pure white, beautiful.

"Delice," full and perfect, soft pink.

"Admiral Dewey," large and full "American Beauty."

\section{Decorative Dahlias}

No. 1 "Golden Yellow."

"Jack Rose," rich crimson redmaroon shadings.

"Sylvia," fine and full to center, white, shaded pink.

Mrs. Winter," pure white.

"Lavender," Pink, sprinkled cherry red.
"Heliotrope," shaded deep purple.

"Striped Banner," Crimson topped white.

“Midnight," flat, velvety petals, dark, nearly black.

“Gustav Dousan," orange red, very large (7 inches), petals broad and flat.

Pompon Dahlias

"Snowclad," pure white, lovely, a little beauty.

"Little Mars," scarlet; a perfect flower.

\section{Cactus Dahlias}

Countess of Lonsdale, free bloomer. Krimhilde, deep pink, lighter in center.

Zulu, dark, nearly black.

Price each, labeled, $10 \mathrm{c}$, or $\$ 1.00$ per 12 , postpaid.

Price each, unlabeled, $5 c$, or $50 \mathrm{c}$ per 12 , not prepaid.

\section{SPRAYING MATERIAL}

I will endeavor to keep on hand Lime Sulphpr Solution and Dry Arsenate of Lead. However, I can not at this time quote a price for the same.

I have on hand a lot of Sulfo-Tobacco Soap, 3-ounce cakes, 10c; 8-ounce cakes, 20c. This is excellent for the protection of houseplants and rose bushes.

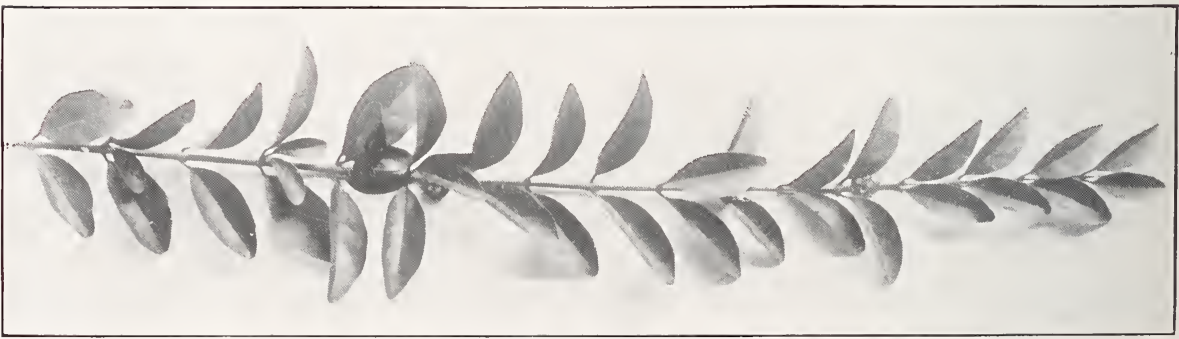




\section{STRAWBERRIES}

In Strawberry growing, soil, location, and care form the tripod of success. SOIL-Any land that will grow a maximum crop of corn or potatoes will also grow strawberries, if the other factors are right.

LOCATION-Low, swampy ground, or dry knolls should be avoided, as Jack Frost will get your berries on the one and drouth on the other.

CARE-Choose a rich piece of ground that has been cultivated for several years and is clear of sods or weeds. Plant early in spring in rows 24 to 30 inches apart for hand culture, or from 3 to $3 \frac{1 / 2}{2}$ feet for field culture, with plants from 12 to 18 inches apart in the row; however, plant close to let the rows fill up with plants early in the season. Keep the ground well cultivated and free from weeds, and later, when the rows are well filled with plants, cut away all surplus runners.

At the approach of cold weather, place a clean mulch between the rows, but not on top of the plants until the ground is frozen. In the spring, if your mulch is thick on the plants remove a part, so that the plants may be able to grow up through, but leave that between the rows, it will keep the ground from drying out, keep out weeds and also keep your berries clean.

\section{Varieties unless marked, 50c per $100 ; \$ 3.50$ per 1000 .}

Warfield (imperfect). Productive and good.

Senator Dunlap (perfect). A good companion to Warfield. Two good table berries and the only berries that are firm and of a color that makes them show up in the cans - enough said.

\section{"Gibson," "Pocomoke," “Glen} Mary." Three perfect bloomers. While not alike in every respect, all three are large berries, productive and good.

"Gandy."
"Kellogg's Pride." Both perfect blossoms; berries large and late in ripening.

Haverland (imperfect). An early berry, hardy in plant and blossom, very productive; ripens all the fruit; very profitable for market.

Charles I (perfect). A large early berry well worth a trial.

"Superb."

"Progressive." Two fall-bearing varieties with perfect blossoms. Superb does a little the best with me. 50 c per $12 ; \$ 1.50$ per 100 .

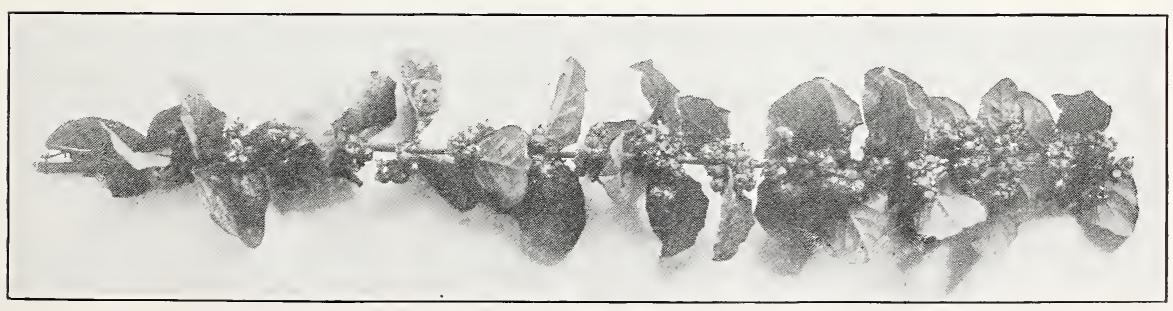




\section{RASPBERRIES}

"Cuthbert," or Queen of the Market, too well known to need description. 25c per 12; $\$ 1.25$ per 100 .

"Golden Queen," a seedling of the Cuthbert with golden yellow fruit. 50 c per 12; $\$ 2.00$ per 100 .

"St. Regis," an ever-bearing variety. It will bear the season planted, both on the old wood in July and on the new growth in the fall. 50c per 12; $\$ 1.50$ per 100 .
"Columbian," is a dark red or purple berry of large size and the best quality; very productive and hardy; does not sucker. 50c per 12; $\$ 1.50$ per 100. Tip plants only.

"Cumberland" (Blackcap). This is a large, firm and productive berry of the highest quality. 50c per 12; $\$ 1.25$ per 100 .

\section{BLACKBERRIES}

"Snyder" is the only kind in the blackberry line-but is good to stick to-sucker plants only, 50c per 12; $\$ 1.50$ per 100 .

\section{CURRANTS}

Fay's Prolific. A large red fruit. 10c each; \$1.00 per 12.

\section{GOOSEBERRIES}

"Smith's Improved" and "Hough- latter a red berry of medium to large ton" are the only two kinds I carry in size. Both are hardy and productive. stock, the first is a green berry, the 15 c each; $\$ 1.50$ per 12 .

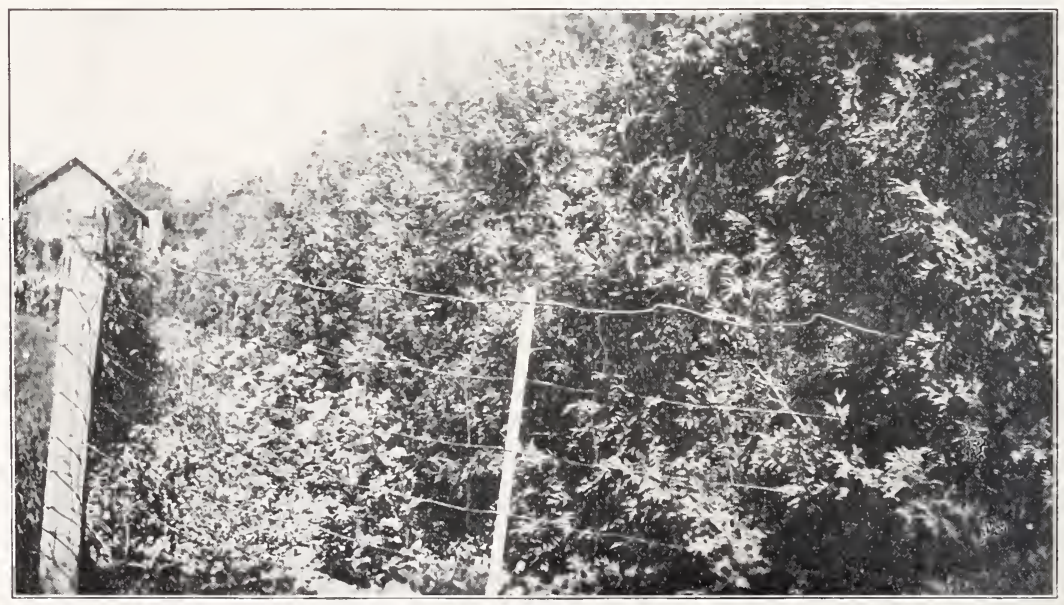

Arbor Vitæ Hedge 


\section{GRAPES}

One can grow grapes in any old place, on the side of the porch, up against the garage, or on the back fence, Plant, if only one or a few vines:

Concord-An old standby, hardy, productive and a good shipper. Strong vines, 10 c each.

Worden-Several days or a week earlier than Concord; a sweeter and better grape for home use or near by market. 10c.

Moore's Early_An all around good grape with large berries and compact bunches; ripens long before frost and opens the season at least ten days ahead of Concord. 10c each.

Campbell's Early-This is not only a good black grape, but it is also early and can be kept a month or more after picking. 25c each.

Niagara-A standard white grape; a strong grower; berries are large, bunches compact; it ripens with Concord or a little sooner. Two-year Vines, $15 \mathrm{c}$ each.

Moore's Diamond - A grape of quality; sweet and good; ripens ahead of Niagara. Two-year Vines, 15 c ea.

\section{FRUIT TREES}

I have on hand the following Fruit trees:

Apple, at 25c each.

Astrachan.

Duchess Oldenburgh.

Yellow Transparent.

Wealthy.

Snow.

Delicious.

Wagner.

Transcendent Crab.

Hyslop Crab.

Martha Crab.

Also a few

Grimes Golden.'

Early Strawberry. ?

Fallman.

Staymans.

\section{Cherries, 35c.}

Early Richmond.

L. Montmorency.

Sweet Cherries, 50c.

Windsor.

Black Tartarian.
Pears, 35c

Wilder, early.

Duchess Ang.

Clapp's Favorite.

Bartlett.

Flemish Beauty.

Kiefer.

Anjou.

Plums, 35c.

Lombard.

Burbank.

German Prune.

Shippers' Pride.

Peach, 25c.

Crosby's Early.

Apricots, 25c.

Budd.

The above stock of fruit trees is limited and orders for the same should come in early, as they can not be duplicated for the price I ask. 
E VER G R E N N UR S R Y, SA G I A W,

M I C H I G A N

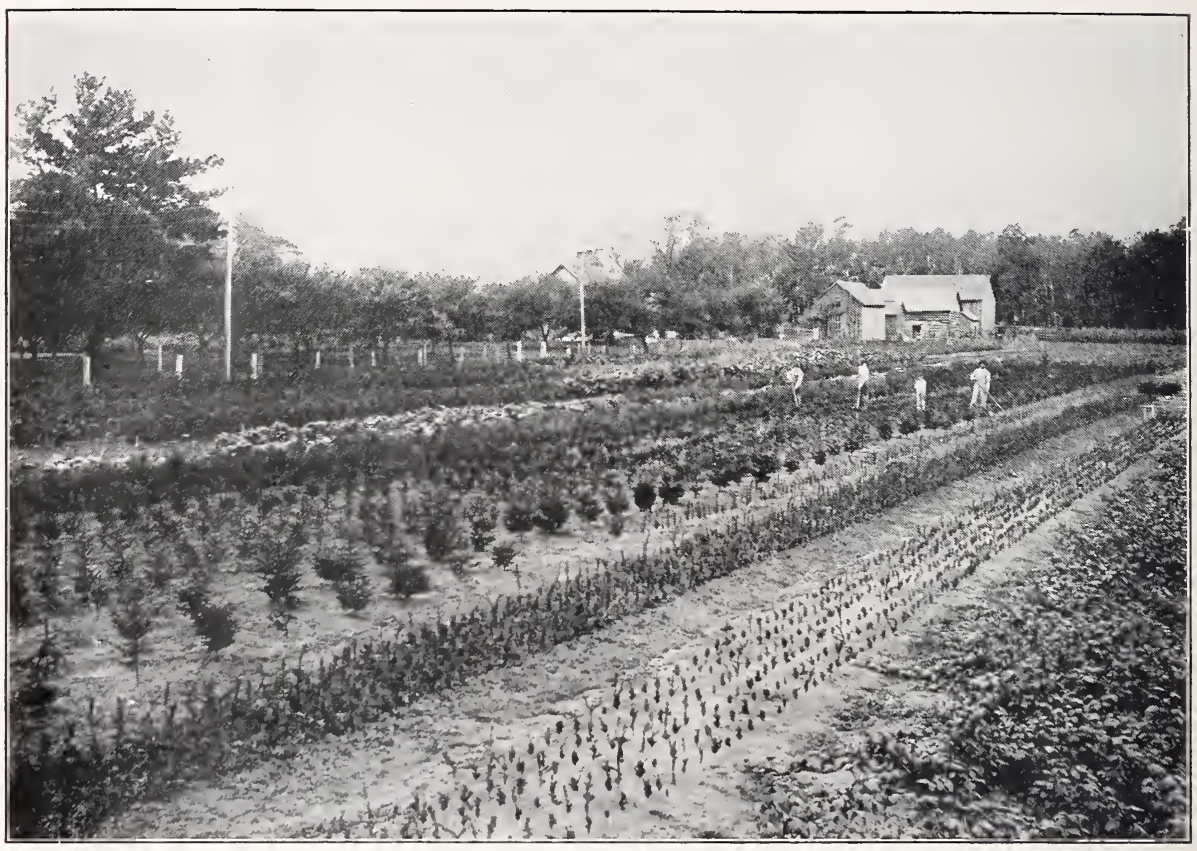

Then

\section{Norway Spruce}

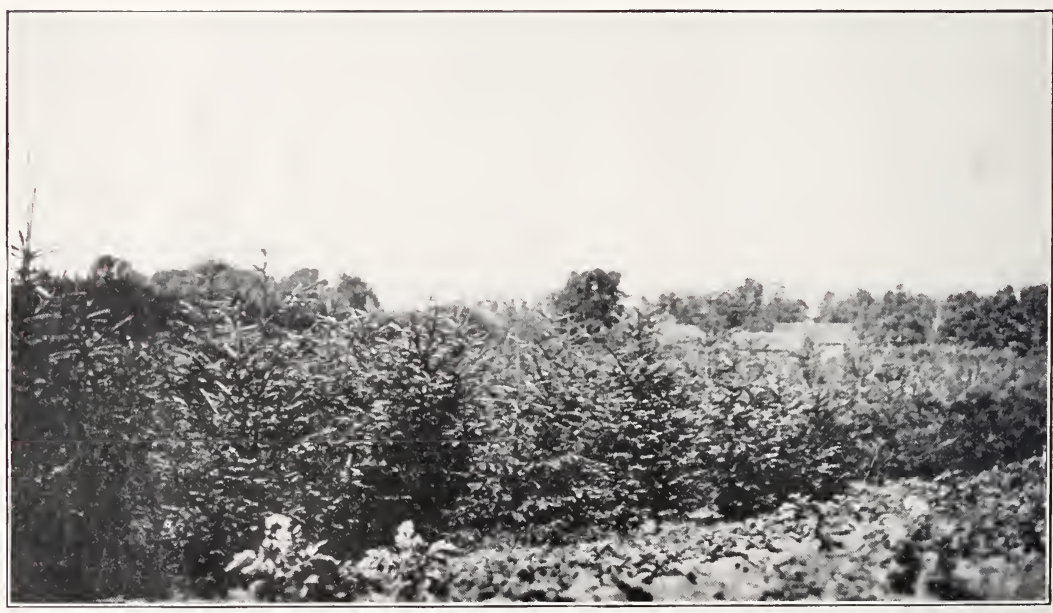

Now 


\section{BULBS FOR FALL PLANTING}

As we have not the time to get up a Fall Price List, we are compelled to insert here a list of Bulbs that are not planted at any other time but Fall. Therefore it is well to preserve this catalog until Fall.

We have a goodly selection of Bulbs and increase our stock as fast as we get acquainted with new and better varieties.

This class of plants is hardy. They can endure almost any neglect short of digging up, and will root in the hardest of soil and even in the lightest sand, pushing their flower stems through the frozen ground, it seems, and unfolding their flowers in the spring sunshine, while the snow still lies deep in shady places.

\section{SINGLE EARLY TULIPS}

$25 \mathrm{c}$ per 12 .

Cottage Maid-White, shaded pink.

Chrisolora-Pure golden yellow.

White Hawk-Pure white.

Artus-Deep red.

Imperial Crown-Red and yellow.

Thomas Moore-Orange.

Duchesse of Parma-Scarlet, edged yellow.

MAY FLOWERING OR COTTAGE TULIPS

Macrospeila-Crimson.

Gesneriana Spatula-Scarlet.

Gesneriana Lutea-Yellow.

Picottee-White and blush.

White Swan-Pure white.

Golden Crown-Yellow, bordered red.

\section{DOUBLE TULIPS}

$25 \mathrm{c}$ per 12.

Crown of Gold-Yellow.

Rex Rubrum-Crimson scarlet.

Salvator Rosa-White and rose.

Tournsoll-Bright red, yellow margin.

\section{DARWIN TULIPS}

$50 \mathrm{c}$ per 12 .

Baronne Tonnaye-Carmine rose.

Margaret-Blush white.
Bride of Harlem-Carmine rose, tinted lilac.

Zulu-Purplish black.

\section{PARROT TULIPS}

$25 \mathrm{c}$ per 12 .

Perfecta-Gold and scarlet.

Crimson Brilliant--Sweet scented.

\section{NARCISSUS AND DAFFODIL}

$25 \mathrm{c}$ per 12 .

Golden Spur-Golden yellow.

Victoria Bicolor-Yellow and cream.

Van Sion-Double Daffodil.

Incomparable-Butter and eggs.

Albus Plenus-Double white, late.

Paper White Grandiflora.

Double Roman-Cream and orange.

\section{SINGLE HYACINTHS}

$50 \mathrm{c}$ per 12 .

Dark Blue, Light Blue, Red, Pink, Salmon, Yellow, and White.

\section{CROCUS}

$10 \mathrm{c}$ per $12 ; 70 \mathrm{c}$ per 100 .

Purple, Yellow, White, and Striped.

\section{GRAPE HYACINTH}

$10 \mathrm{c}$ per 12 .

\section{SNOW DROPS}

15c per 12 . 


\section{SPRAYING}

You may have the finest orchard on the highest priced land; you may cultivate and prune; but the countersign to success is SPRAY. One very big drawback in the past has been the great number of insect and fungus enemies, as well as the great number of remedies to be applied for each. Of late years the discovery has been made that the lime sulphur solution will kill the spores of blight, as well as scale insects, by contact, and if we add a little arsenate of lead we also kill insects that chew, as well as the apple worm.

If we arrange for the spraying in a systematic manner - three or four sprays a year - we will save the orchard and protect the fruit.

First Spray.-After the leaves have fallen in the fall, but before the buds open in the spring, take five gallons of the concentrated lime sulphur solution to from 40 to 45 gallons of water; cover the tree from both sides, the large branches as well as the body of the tree. This so-called dormant spray will have killed all the eggs of the tent caterpillar, the eggs of the green fly (Aphis), oyster-shell bark louse, and above all things else the San Jose scale, besides the spores of the blight and other fungi that it has come in contact with. This may be applied to all trees, shrubs and vines and even on some evergreens.

Second Spray.- Spray after the petals have fallen, for the Codling moth and other insects that may have escaped the winter spray; also for the curculio and possible spores of blight. Remedy: One gallon lime sulphur solution to fifty gallons of water and two pounds of arsenate of lead.

Third Spray.-Ten days after, repeat on apples, pears and plums. At this time use half a pound of arsenate of lead to $12 \frac{1}{2}$ gallons of water.

Fourth Spray.-Spray about July 25 th on all late apples, one pound of arsenate of lead to 25 gallons of water. The time for this spray may vary with the season.

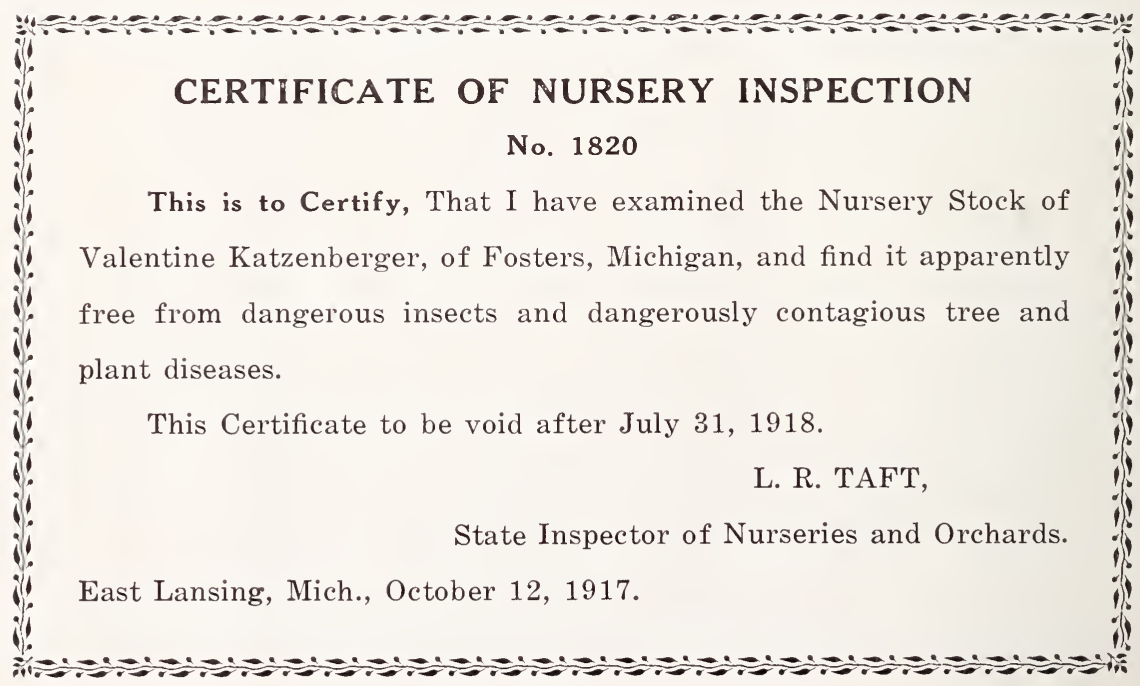


EVERGRE N N URSERY, SAG I NAW, M I C I G A N

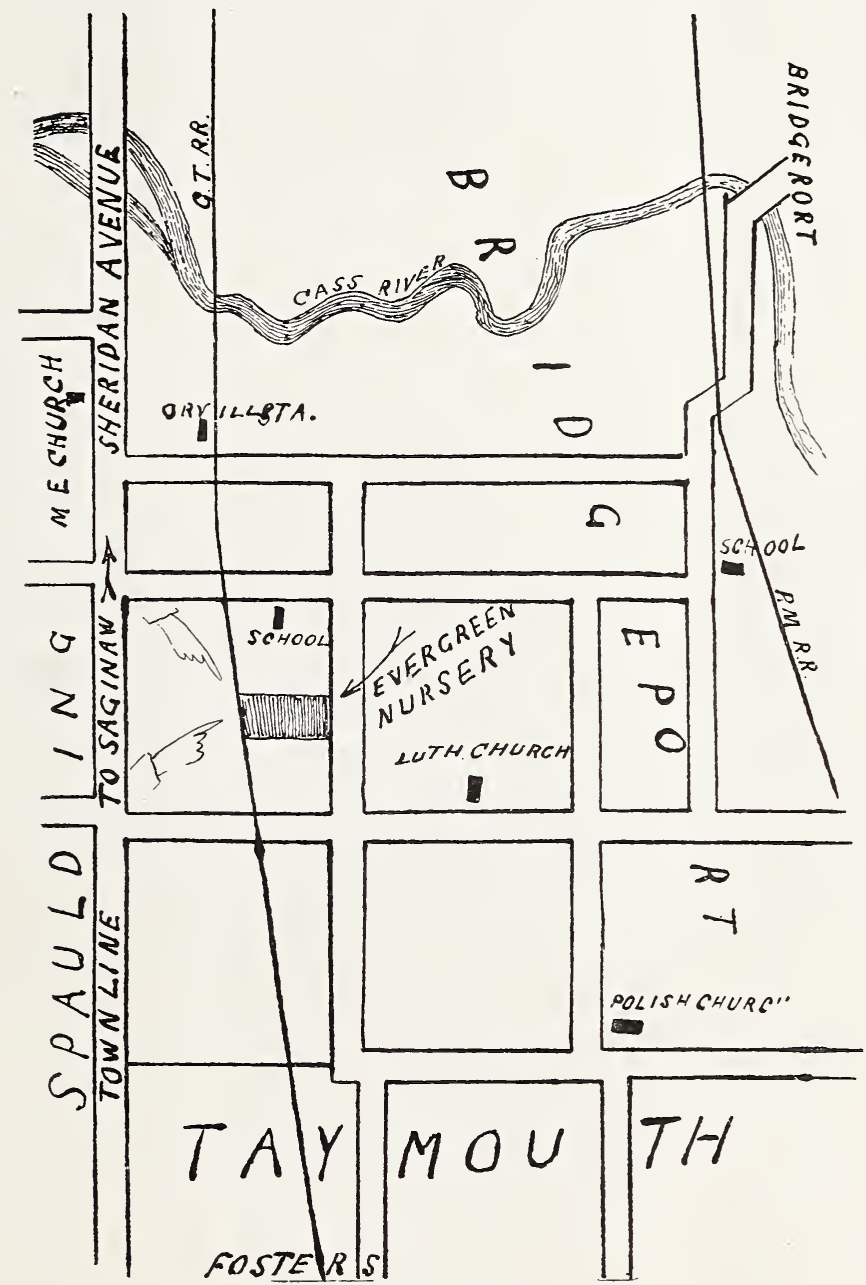




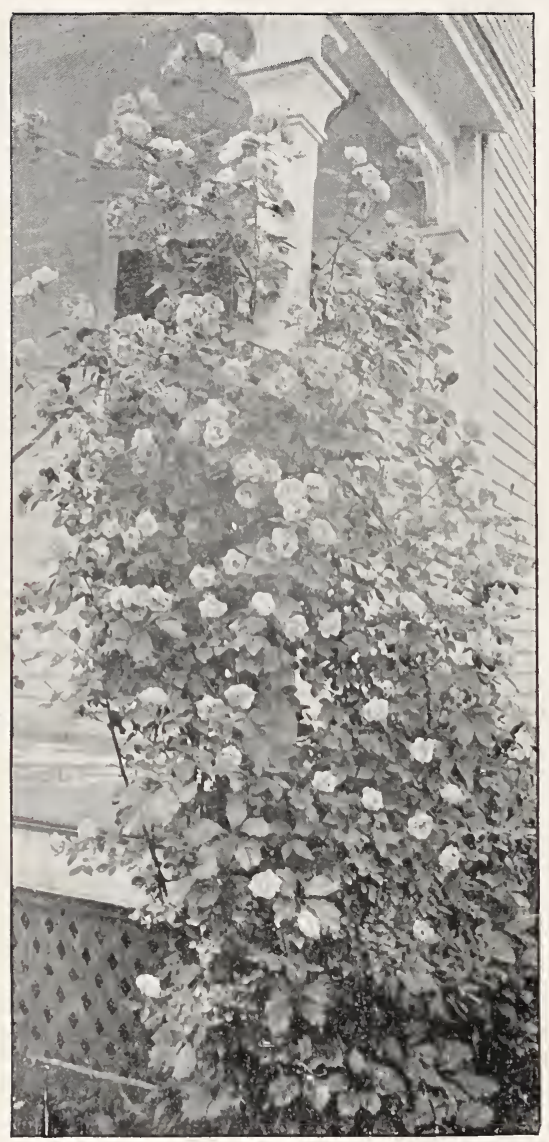

Queen of the Prairie 